\title{
Once Again on the Pella Curse Tablet
}

\author{
Robert A. Sucharski \\ (University of Warsaw)
}

\begin{abstract}
The Pella curse tablet contains the word $\triangle$ AГINA. This paper proposes to treat it as an etymological cognate of the gloss $\theta \eta \dot{\gamma \varepsilon \varepsilon} \alpha$, which we owe to Hesychius. If this is true, we may interpret the Theocritean hapax $\delta \alpha \gamma \tilde{u} \varsigma$ as a Macedonian loan word.
\end{abstract}

\section{Keywords}

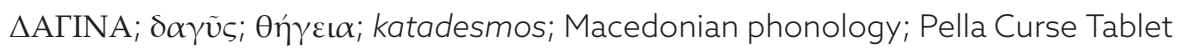

Probably the most famous definition of Greekness we owe to Herodotus (VIII, 144, 2): $\tau$ ì

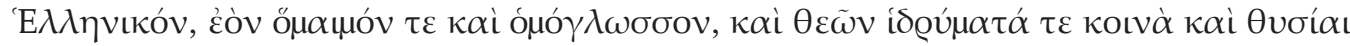

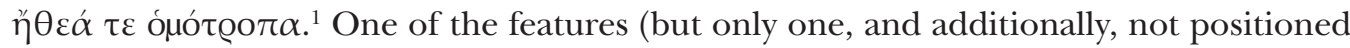
in the first place) granting humans the virtue of being Greek is therefore the use of the common Hellenic language. On the other hand, we know that Greek - through its fascinating and extremely long period of being attested in the phonetic script - has never been uniform. It is worth thus indicating what features are at present considered specifically Greek and allow us to distinguish Greek from the other Indo-European idioms.

In the present paper we are interested first of all in phonology/phonetics. In this context, James Clackson (in his paper The genesis of Greek, published in the monograph edited by Anastasios-Foivos Christidis) points to seven isoglosses specific to the ProtoGreek (Clackson 2007: pp. 187-188):

- the development of a series of voiceless aspirated plosives $\left(p^{h}, t^{h}, k^{h}\right)$ from the reconstructed voiced aspirated plosives $\left(* b^{h}, * d^{h}, * g^{h}, * g^{h},{ }^{2} * g^{w h}\right),{ }^{3}$

- the development of the glottal fricative [h] from *s before a vowel at the beginning of a word or between vowels,

- the loss of the glide *y between vowels,

\footnotetext{
* I would like to thank Dr. Elżbieta Olechowska for improving my English.

1 " [...] the kinship of all Greeks in blood and speech, and the shrines of gods and the sacrifices that we have in common, and the likeness of our way of life [...]". [Transl. A. D. Godley; retrieved 7. 9. 2016 from http://www.perseus.tufts.edu].

2 In the book printed as * $g^{h}$ presumably because of the 'kentum-ness' of Greek.

3 The contributors to the monograph do not take into account the so called 'glottalic theory'. Neither is this theory otherwise referred to in the paper.
} 
- the loss of all but $r, n, s$ consonants at the end of the word,

- the specific development of the PIE laryngeals,

- the specific development of the PIE liquid, nasal, and glide sonorants,

- the maintenance (although limited to the last three syllables) of the PIE pitch accent.

The feature mentioned by Clackson first has usually served as an indirect proof that the ancient Macedonian does not belong to the group of idioms that may be considered Greek. The lexical material, limited to onomastics and especially to personal names, indicates that consonants in the Macedonian names went through a different evolution of the PIE voiced aspirated plosives: unlike what happened with Greek consonants, they retained their voicing, but they did lose the aspiration. Thus the question of Greekness of Macedonian is very far from being solved - let us use the conclusion of Anna Panayotou: "Macedonian is now generally studied within the context of the Greek dialects, but that does not mean that all the problems have been resolved as early (archaic and classical) inscriptions are scanty." (Panayotou 2007: p. 433). A somehow similar quotation, but this time about the people, not the language, we read in Johannes Engels' paper: "This chapter has supported the view that Hellenic and Macedonian ethnic identity or ethnicity should be regarded as extremely complex and fluid social constructions which surely deserve further study." (Engels 2010: p. 97). One may say non liquet (at least, yet).

As already stated, the lexical and phonological/phonetic material present in the personal names is the most important for analysis, mainly because texts are scarce. It may, of course, happen, as Panayotou suggests, that the Macedonian names manifesting phonetic/phonological otherness "are substratum relics of a tribe which lived in the region and which was linguistically assimilated by the Macedonians" and "that as early as the fifth century BC the only traces of this language were confined to one of the most conservative of areas, that of onomastics or religion." (Panayotou 2007: p. 439).

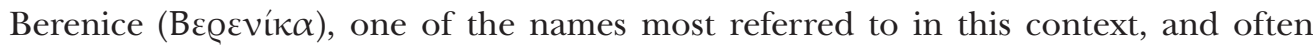
denoting the female members of the Ptolemaic Dynasty ruling in Egypt, is a perfect

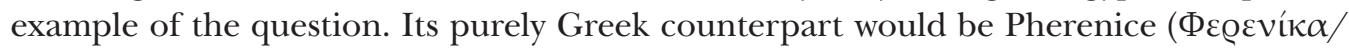

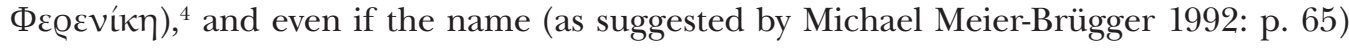
were a Greek loanword, the fact that it took on the Macedonian phonetics, would undoubtedly indicate that the Macedonian counterpart of the Greek $/ \mathrm{p}^{\mathrm{h}} /$ is $/ \mathrm{b} /$.

The same reasoning, i.e. based on the belief in regular adequacy of Greek and Macedonian phonemes, enabled Olivier Masson to convincingly propose the understand-

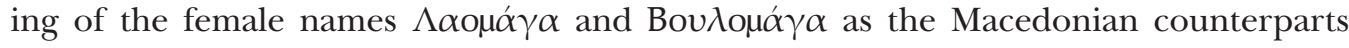

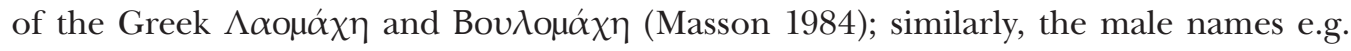

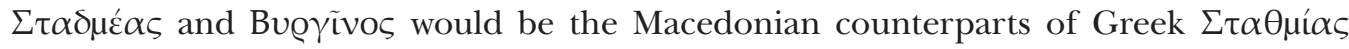
and Фv@кĩvos (Masson 1998). We may find other examples of such adequacy in Miltiades Hatzopoulos' paper (Hatzopoulos 2000).

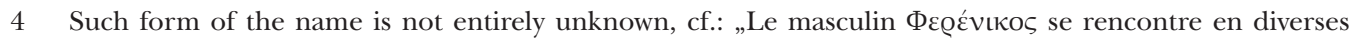
régions, notamment au centre et au nord de la Grèce, même en Attique [...] et le féminin a dû exister

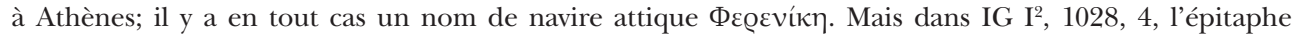

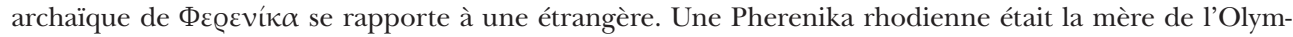
pionique Peisirrhodos [...].” (Masson 1984: n. 1). 
We may go further - assuming such an adequacy might be helpful in proposing another understanding of a crucial point in the Pella curse tablet. The katadesmos, $30 \mathrm{~cm}$ long lead scroll, found in August 1986 and dated for ca. $1^{\text {st }}$ half of the $4^{\text {th }}$ cent. BC, was preliminary published by Emmanuel Voutiras (Voutiras 1993). It is written in a variation of north-western (Doric) Greek, but contains twelve letters $\triangle$ АГINАГАРIME whose meaning could not have yet been established with certainty. We owe the analysis of the problem to Laurent Dubois. The French dialectologist reads the last six letters as $\gamma \alpha \dot{\varrho}$ cưu, while showing other vowel hesitations (hésitations vocaliques) in the tablet, and proposes to interpret $\triangle \mathrm{A} \Gamma \mathrm{INA}$ as $\delta \alpha \pi \mathrm{t} v \alpha$, which finally enables him to recognize the

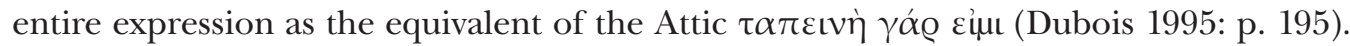
Of course, we cannot exclude a graver's mistake in writing $\Gamma$ instead of $\Pi$ or monophthongization and phonetic closure of [e] into [i] in the Greek dialects of that period (e.g. Bartoněk 1972: pp. 124-156) - the tablet indeed contains some graving errors (Panayotou 2007: pp. 441-442). However, the necessity of accepting still another graver's error - unspoken by Dubois - namely that of graving $\Delta$ instead of $\mathrm{T}$, renders the hypothesis much more problematic.

The true question is what $\triangle \mathrm{A} \Gamma \mathrm{INA}$ actually means - the context of the katadesmos might lead to the conclusion that it could be a personal name or a specific term, somehow connected with magic. The word previously unattested either in Greek or in Macedonian might have however a Hellenic explanation, if we accept the adequacy of plosives in personal names: the Greek voiceless aspirated stops as opposed to the Macedonian voiced and non-aspirated, i.e. the hypothesis which enabled Masson to explain some problems in Macedonian onomastics.

In the Hesychius' Lexicon we find an obscure (crux philologorum) entry (n. 458): $\uparrow \theta \eta ́ \gamma \varepsilon \iota \alpha \cdot \theta \alpha u \mu \alpha \sigma \tau \alpha \dot{\alpha} . \psi \varepsilon v \delta \tilde{\eta}{ }^{5}$

The Greek translation of the word quoted by Hesychius leaves no place for doubt in in-

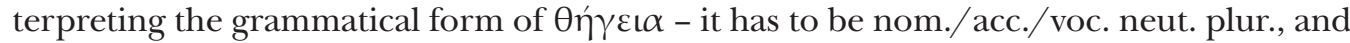
its meaning leads us into the world of fantasy, fairies, and sorcery. We cannot be sure, whether the word actually existed in this form, from where Hesychius could have taken it, and how he could have pronounced it. Should the spelling be decisive here (despite the Greek pronunciation of the fifth and sixth century AD), we would have the perfect phonetic match to $\triangle \mathrm{A} \Gamma \mathrm{INA}$ - nobody can be certain of the length of the first vowel [a]. The stem $\theta \eta \gamma-/ \theta \bar{\alpha} \gamma$ - remains however undetermined: the only possible IE stem ${ }^{*} d^{h} e h_{2}{ }^{-}$, because of its meaning ('schärfen, wetzen', LIV': p. 140), does not seem semantically

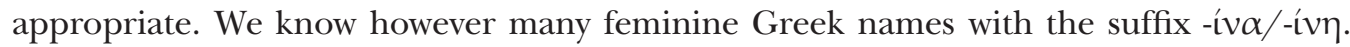
The Lexicon of Greek Personal Names (LGPN) has not been completed yet, but thanks to its digitalization we are able to search and analyse on-line more than 35 thousand names, published so far. ${ }^{6}$ Thus in the already published volumes we find 166 attested feminine names ending in -ív $\alpha$ and 86 ending in -ívๆ. Some of them are evidently of Latin origin

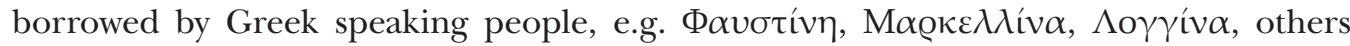

5 The Greek quotations after the edition in the Thesaurus Linguae Graecae on-line. [Retrieved 17. 9. 2016 from http://stephanus.tlg.uci.edu ].

6 [Retrieved 17. 9. 2016 from http://www.lgpn.ox.ac.uk/online/index.html]. 


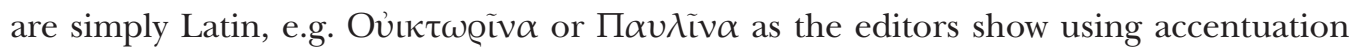
marks. Nevertheless, a big part of the names may be reasonably treated as Greek and what is even more important they are quite frequent in the Vol. IV of LGPN which contains the names attested in Macedonia, Thrace and the northern shores of the Black Sea. It is thus tempting to see in $\triangle \mathrm{A} \Gamma \mathrm{INA}$ another example of a feminine autochthonic name or a technical term with the meaning of 'sorceress'.

If our reasoning up till here appears rational, we may go further. We owe to Theocritus the technical term for a puppet or doll used in magic: $\delta \bar{\alpha} \gamma \tilde{v} \varsigma$ (Theoc., Id. 2,110 ). ${ }^{7}$ The term occurs when Simaetha abandoned by Delphis performs a ritual of love magic to regain emotions of her perfidious lover. Could we consider the Greek word $\delta \alpha \gamma \tilde{v} \varsigma$ a Macedonian loan?

\section{Bibliography}

Bartoněk, A. (1972). Classification of the West Greek Dialects at the Time about 350 B.C. Prague: Publishing House of the Czechoslovak Academy of Sciences.

Christidis, A.-F. (Ed.). (2007). A History of Ancient Greek. From the Beginnings to Late Antiquity. Cambridge: Cambridge University Press.

Clackson, J. (2007). The genesis of Greek. In A.-F. Christidis (Ed.), A History of Ancient Greek. From the Beginnings to Late Antiquity (pp. 185-192). Cambridge: Cambridge University Press.

Dubois, L. (1995). Une table de la malédiction de Pella: s'agit-il du premier texte macédonien? Revue des Etudes Grecques, 108 (janvier - juin 1995), 190-197.

Engels, J. (2010). Macedonians and Greeks. In J. Roisman, \& I. Worthington (Eds.), A Companion to Ancient Macedonia (pp. 81-98). Chichester: Wiley-Blackwell.

Hatzopoulos, M. (2000). 'L'histoire par les noms' in Macedonia. In S. Hornblower, \& E. Matthews (Eds.), Greek Personal Names: Their Value as Evidence (Proceedings of the British Academy, 104; pp. 99-117). Oxford: Oxford University Press.

Hornblower, S., \& Matthews, E. (Eds.). (2000). Greek Personal Names: Their Value as Evidence (Proceedings of the British Academy, 104). Oxford: Oxford University Press.

LIV = Rix, H. et al. (2001). Lexikon der indogermanischen Verben. Die Wurzeln und ihre Primärstammbildungen (2. ed.). Wiesbaden: Dr. Ludwig Reichert Verlag.

Masson, O. (1984). Quelques noms de femmes en Macédoine. Zeitschrift für Papyrologie und Epigraphik, 55, 133-136.

Masson, O. (1998). Quelques noms macédoniens dans le traité IG I² $71=\mathrm{I}^{3}$ 89. Zeitschrift für Papyrologie und Epigraphik, 123, 117-120.

Meier-Brügger, M. (1992). Griechische Sprachwissenschaft, Bd. I: Bibliographie, Einleitung, Syntax. Berlin-New York: Walter de Gruyter.

Panayotou, A. (2007). The position of the Macedonian dialect. In A.-F. Christidis (Ed.), A History of Ancient Greek. From the Beginnings to Late Antiquity (pp. 433-443). Cambridge: Cambridge University Press.

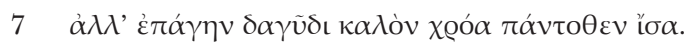


Roisman, J., \& Worthington, I. (Eds.). (2010). A Companion to Ancient Macedonia. Chichester: WileyBlackwell.

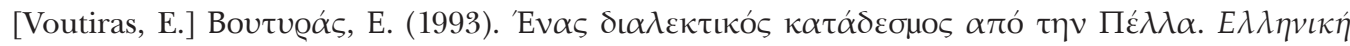

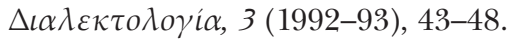

Prof. Robert A. Sucharski / sucharsk@al.uw.edu.pl

University of Warsaw, Faculty of "Artes Liberales"

Nowy Świat 69, 00-046 Warszawa, Poland 
